УДК 343.976

DOI https://doi.org/10.32837/yuv.v0i3.2192

\author{
А. Градецький, \\ кандидат юридичних наук, доцент, \\ доцент кафедри службово-бойового застосування Національної гвардії України \\ Київського факультету \\ Національної академії Національної гвардії України \\ О. Повар, \\ старший викладач кафедри із забезпечення державної безпеки \\ Київського факультету \\ Національної академії Національної гвардії України
}

\title{
НАРКОТИЗМ ВІЙСЬКОВОСЛУЖБОВЦІВ ЯК СОЦІАЛЬНО-ПРАВОВА ПРОБЛЕМА
}

Постановка проблеми. Конституція України у ст. 3 проголошує здоров'я людини найвищою соціальною цінністю. За останне десятиліття в Україні проблема вживання наркотиків перетворилася на загрозу здоров'ю населення, а наркоманія у важку хворобу, що руйнує психофізичне здоров'я людини. Наркозалежність стала для України загрозливим викликом нації й державі. Так, органи і підрозділи Національної поліції в період з вересня 2019 року до серпня 2020 року задокументували понад 31471 факт кримінальних правопорушень у сфері незаконного обігу наркотиків. Порівняно з аналогічним періодом динаміка становить $+7 \%$ (з вересня 2018 року до вересня 2019 року - 29 451). Дослідження стану криміногенної ситуації показує постійне збільшення обігу наркотичних засобів та числа наркозалежних осіб, а за темпами зростання кількості злочинів, пов'язаних 3 ними, Україна посідає одне з перших місць у світі [1, с. 5].

Ситуація сьогодення свідчить, що немедичне вживання наркотичних та психотропних речовин має тенденцію до швидкого поширення, причому вік наркоманів стабільно знижується. Згідно зі статистикою, щорічно в Україні близько 150 тис. молодих людей стають наркозалежними, 95\% з яких - це молодь віком 15-30 років, а кожен п'ятий наркоман - жінка. Щорічні збитки держави від незаконного обігу наркотиків сягають понад 3 млрд доларів. За добу в країні помирає 330 наркоманів, а за рік це число становить 120 тис. осіб. Загалом на обліку в медичних установах держави перебуває понад 100 тис. хворих на наркоманію. У науковій літературі під терміном «наркоманія» розуміється хворобливий психічний стан, що зумовлений хронічною інтоксикацією внаслідок вживання наркотичних засобів, який характеризується психічною або фізичною залежністю від них [2, с. 22].

Проблеми незаконного обігу наркотичних речовин, детермінації та запобігання наркозлочинності були досліджені в працях вітчизняних і зарубіжних науковців: Ю.В. Александрова, М.І. Бажанова, Ю.В. Бауліна, А. Верде, А.А. Габіані, В.В. Голіни, Б.М. Головкіна, В.К. Грищука, O.M. Джужи, А. Джеретті, А.І. Долгової, В.П. Ємельянова, В.І. Женунтія, А.П. Закалюка, М.Й. Коржанського, В.В. Лунєєва, А.А. Музики, Д. Реймана, В.Я. Тація, В.О. Тулякова, І.К. Туркевич, М.С. Хруппу, Д.Ф. Шеллі, О.В. Шеслера та багатьох інших дослідників. Проте в криміно- 
логічній літературі відсутні концептуальні дослідження, що відображають сучасні проблеми наркотизації та наркозлочинності, а також шляхи їх вирішення у військово-правовій сфері.

Метою статті $є$ дослідження проблеми розповсюдження наркоманії серед військовослужбовців, а також установлення взаємозв'язку вживання наркотичних речовин та скоєння військовослужбовцями кримінальних правопорушень.

Виклад основного матеріалу. Результати проведених наукових досліджень показують, що реальні масштаби зловживання наркотичними засобами та сильнодіючими речовинами в кілька разів перевищують дані офіційної статистики. Зважаючи на латентність наркоманії, дослідники вважають реальним уявлення про кількість наркоманів в Україні 450-500 тис. осіб, а це понад $1 \%$ усього населення. Фахівці вважають, що з кожним роком майже на $8 \%$ збільшується кількість українців, які є наркозалежними.

Поширеність наркоманіі серед цивільного населення зумовлює $\dddot{11}$ наявність і серед військовослужбовців. Серед контингенту призовників і чоловіків мобілізаційного віку сформувалася велика частка осіб, які мають досвід вживання наркотиків. За даними соціологічних досліджень, $35 \%$ першокурсників професійно-технічних училищ та $25 \%$ студентів вищих навчальних закладів пробували наркотики [3, с. 43-44]. Неповнолітні та молодь, які страждають від наркотичної залежності, $€$ основною групою ризику і одночасно головним «резервом» військового наркотизму. Наркотизм - антисуспільне явище, яке виявляється у незаконному вживанні наркотичних або психотропних речовин, а також у вчиненні на цьому грунті протиправних дій з цими речовинами, відповідальність за які передбачена адміністративним і кримінальним законодавством [4, с. 121-122].
Неналежної якості медичний огляд молоді призовного віку, руйнування системи військово-професійної орієнтації та підготовки юнаків до військової служби, відсутність ефективної системи комплектування Збройних сил та військово-професійного відбору уможливлюють зарахування у війська молодих людей, схильних до наркоманії.

Важливо, що у сучасних умовах, коли ускладнюється геополітична обстановка, з'являються нові загрози i виклики, відбувається оснащення військ сучасною зброєю, отже, питання фізичного, психічного і духовного здоров'я особового складу військових формувань України набуває актуальності, оскільки наркотизація військовослужбовців є загрозою для військової безпеки нашої країни. Військовослужбовці, що вживають наркотичні засоби, не можуть пильно нести службу. Відомо, що серед негативних наслідків вживання наркотиків є зниження розумових та фізичних здібностей, послаблення пам'яті та нестійкість темпераменту, різке зниження трудового, духовно-морального, інтелектуального і творчого потенціалу. Тому наркоманія несумісна з військовою службою, яка відрізняється напруженою інтелектуальною діяльністю, виконанням обов'язків, що вимагають значних фізичних і психологічних навантажень [8, с. 189]. Військовослужбовець, що вживає наркотичні речовини, здатний на будь-які непродумані дії. Така ситуація небезпечна не лише зрозумілою загрозою для життя і здоров'я, яку несе військовослужбовець у стані наркотичного сп'яніння, але й тим, що створює серйозні передумови для надзвичайних подій та аварійних ситуацій із непередбаченими наслідками, сприяє поширенню девіацій, перш за все суїцидальних проявів, призводить до небойових втрат серед військовослужбовців. У 2016 році кількість небойових втрат становила 256 осіб, тоді як бойових - 211. 3 них 
63 військовослужбовці загинули внаслідок скоєного суїциду. Саме самогубства перебувають на першому місці як причина загибелі військовослужбовців не в умовах безпосереднього ведення бою [5, с. 5].

Наркоманія є одночасно проблемою соціальною, психологічною, медичною і правовою. Разом із тим вона має особливо виражений кримінологічний аспект. Зростання наркозлочинності військовослужбовців простежується щорічно. На грунті вживання наркотиків скоюються загальнокримінальні та «військові» кримінальні правопорушення. Наприклад, у першому півріччі 2016 року кримінальні правопорушення, пов'язані із незаконним обігом наркотичних речовин, становили 5,6\% (78) від загальної кількості. В зоні проведення АТО за цей же період вони становили $15 \%$ (42) від загальної кількості кримінальних правопорушень [6, с. 50-51].

Кримінальні правопорушення, що пов'язані з наркотизмом у військових формуваннях, можна поділити на три основні групи:

- контрабанда та незаконний обіг наркотичних засобів (ст. 305-317 KK);

- порушення у сфері легального обігу наркотичних засобів (ст. 318$322 \mathrm{KK})$;

- загальнокримінальні «військові» кримінальні правопорушення, що вчиняються під впливом наркотичних засобів (ст. 406-416 KK та ін.).

Наркотизація виступає однією 3 причин віктимізації військовослужбовців, у сукупності з іншими формами правопорушуючої поведінки генерує деструктивні чинники в організації бойової діяльності, виступає одним 3 джерел економічного «підживлення» корупції у військових формуваннях.

Також загальновідомо, що вживання наркотиків потребує фінансових ресурсів, що може призвести до крадіжок військового майна та формування дилерської мережі. Зрозу- міло, що таку мережу наркозалежний військовослужбовець буде будувати у своєму оточенні $[7$, с. 15]. Як свідчать фахівці, у багатьох військових частинах є більш-менш активні наркомани, вони швидко знаходять один одного і потенційних споживачів наркотиків. Часто привнесена наркозалежними військовослужбовцями субкультура злочинного співтовариства трансформується і на поведінку законослухняних осіб, які раніше правопорушень не вчиняли.

Кількість наркозалежних осіб у різних військових формуваннях неоднакова. Практично немає наркоманів у високоспеціалізованих, технічно оснащених військах, і зокрема, в частинах урядового зв'язку, спецназі, частинах радіоелектронної розвідки тощо. Це пояснюється жорсткими вимогами до відбору особового складу. Найчастіше військовослужбовці, що вживають наркотичні речовини, концентруються в підрозділах, де ступінь відповідальності не надто високий (тилові підрозділи, підрозділи забезпечення).

До недавнього часу вважалося, що основними суб'єктами злочинів у сфері незаконного обігу наркотиків $€$ військовослужбовці за призовом, однак нині слід констатувати, що проблема вживання i розповсюдження наркотичних речовин стає актуальною й серед офіцерського складу [8, с. 160].

Загальновідомо, що на поширення наркоманії та наркозлочинності суттєво впливають біологічні, соціально-психологічні та психологічні чинники, також причини й умови соціального, правового, ідеологічного, економічного, політичного та іншого характеру [9, с. 284-290].

Що стосується чинників, що породжують наркозлочинність як різновид злочинності військовослужбовців, то сукупність загальних причин i умов доцільно розділити на три основні групи. Перша група - сукупність соціально-економічних, демографіч- 
них, психологічних і інших причин злочинності, наявних у суспільстві. Вони реалізуються через умови життя, виховання, навчання і професійну діяльність правопорушників до призову (надходження) на військову службу. У військових умовах ці причини реалізуються в злочинній поведінці військовослужбовців через сформовані у них криміногенні якості до служби в армії.

Другу групу становлять загальні причини злочинності, що специфічно переломлюються через армійські умови життя і побуту. Ця група причин своєрідно реалізується в умовах військових формувань: одні 3 них послаблюються або нейтралізуються у військових умовах, інші, навпаки, посилюються. Військове середовище $з$ точки зору наявності умов для поширення наркоманії оцінюється суперечливо. В армії молоді люди стикаються 3 обмеженнями, зумовленими специфікою військової служби, зі строгими рамками військової дисципліни, підвищеною відповідальністю за результати своєї діяльності і поведінку. Регламентація життя і діяльності військовослужбовців, повсякденний контроль з боку командирів і начальників, безсумнівно, перешкоджають незаконному розповсюдженню наркотиків у військовому середовищі. Ускладнює поширення наркоманії в армії і віддаленість більшості військових частин від великих населених пунктів, магістральних шляхів транспортування наркотиків. Разом із тим за багатьма параметрами військові підрозділи $є$ сприятливим середовищем для поширення наркоманії. Військові колективи - це відносно закриті групи, а їх члени мають приблизно однаковий вік, стать, інтереси. Постійне і тісне спілкування зі своїми однолітками, висока психологічна залежність від групової думки, яка часто виправдовує вживання алкоголю і наркотичних засобів, стають чинниками, що сприяють поши- ренню наркоманї серед особового складу строкової служби.

Третя група - суто військові причини і умови, що сприяють вчиненню кримінальних правопорушень військовослужбовцями, і являє собою конкретні недоліки в управлінській, організаційній, дисциплінарній та виховній діяльності командування, виховних органів, органів військової юстиції [8, с. 173-174].

Війська - специфічна частина суспільства зі своїми соціально-економічними, демографічними, організаційно-управлінськими і правовими особливостями. Тому поряд із загальним комплексом криміногенних чинників, що притаманні суспільству загалом, специфічними для військового середовища криміногенними чинниками $€$ також дія комплексу психотравмуючих ситуацій. Потенційно стресовими факторами можна вважити такі як: різка зміна побутових умов, соціального статусу, збільшення фізичних і емоційних навантажень, нездатність подолати труднощі військової служби, високі фізичні, моральні і психологічні навантаження. 3 огляду на те, що в умовах гібридної війни на Сході України сформувався новий комплекс психологічних особливостей ведення бойових дій, можна прогнозувати, що будуть формуватися нові причини i механізми виникнення адиктивної поведінки [10, с. 67-74]. У міру збільшення тривалості служби в умовах театру військових дій серед військовослужбовців, залучених до наркотизації, зростає частка осіб, які раніше не мали наркотичного досвіду, і надалі саме вони становлять більшість серед зловживаючих. Формування наркоспрямованої поведінки серед такої категорії значною мірою зумовлюється впливом хронічного бойового стресу. Зі збільшенням тривалості перебування в бойовій обстановці істотно наростають ознаки особистісної дисгармонії і дезадаптації, знижуються здібності до критичної оцінки наркотизації та їі наслідків для 
власного здоров'я [11, с. 73-76].

Сформована останніми роками криміногенна ситуація з наркотизмом у військових формуваннях України не дозволяє робити оптимістичні прогнози. Навпаки, погіршення наркоситуації в країні загалом та серед неповнолітніх (призовного контингенту) зокрема дозволяє зробити висновок про те, що контингентна «база» для цього виду правопорушень у військах буде розширюватися, якщо вчасно не зреагувати на ці наркозагрози. Серйозним фактором $€$ відсутність системності в питаннях регулювання та реалізації антинаркотичної профілактики серед військовослужбовців [5, c. 7].

Отже, назріла нагальна потреба у забезпеченні військових формувань України науково обгрунтованою i апробованою системою профілактики та протидії наркотизації i наркозлочинності, спрямованої на створення надійних антинаркотичних перешкод. Така потреба обгрунтовується такими факторами: 1) завданнями, що стоять перед військовими формуваннями щодо забезпечення оборони і національної безпеки; 2) негативним впливом вживання наркотиків на стан військової дисципліни і правопорядку і, як наслідок, на стан боєготовності і боєздатності; 3) зосередженням у військах озброєння i бойової техніки, а також іншими факторами підвищеної небезпеки; 4) специфікою військової служби, іï суворою регламентацією, організаційною будовою військових формувань [8, с. 239].

Висновки. Наркотизація населення та пов'язана 3 нею наркозлочинність становлять одну із найбільших проблем сучасної правоохоронної діяльності. Водночас суто реактивна протидія злочинам у цій сфері, що спрямована лише на виявлення, розкриття та покарання, не може вважатися ефективною. Натомість, усе більшої актуальності набуває проактивна діяльність, спрямована на попередження та профілактику злочинів, пов'язаних із наркотиками [12, с. $56-65]$.

Профілактика наркоманії повинна бути цілісною системою організаційних заходів, спрямованих на запобігання проникненню наркотиків у військову частину, розповсюдження і вживання їх особовим складом, на активне виявлення осіб, схильних до вживання наркотиків, і вжиття до цих осіб заходів адміністративного, правового, виховного i медичного характеру [5, с. 6].

В основу профілактики та протидії наркотизації та наркозлочинної поведінки військовослужбовців повинні бути покладені такі принципи і підходи:

1) єдність і спільність дій щодо об'єктів профілактики наркозалежної поведінки військовослужбовців, створення у структурі військових формувань

єдиного органу, що відповідає за забезпечення наркобезпеки у військах;

2) пріоритет застосування «нерепресивних» заходів у попередженні соціальних відхилень, моральне «оздоровлення» та підвищення етичних якостей військовослужбовців шляхом військово-патріотичного виховання молоді, подолання правової безграмотності і нігілізму, створення у військових підрозділах середовища 3 «нульовою» толерантною до наркотиків;

3) залучення до антинаркотичної профілактичної діяльності громадських організацій, релігійних організацій, політичних партій, науковців, бізнес-спільноти;

5) здійснення моніторингу наркозлочинності з метою отримання достовірних прогнозів наркоситуації і своєчасної розробки ефективних заходів протидії;

6) навчання та виховання співробітників - суб'єктів профілактики наркоправопорушень: командування, слідчих, військових прокурорів і суд- 
дів, працівників органів військової поліції;

7) вивчення та застосування успішного досвіду боротьби з наркозлочинністю за кордоном.

Профілактика наркотизму та запобігання детермінованої ним наркозлочинності у військових формуваннях $є$ однією $з$ важливих задач у сфері протидії наркотизації суспільства.

У статті досліджено проблеми розповсюдження наркоманії серед військовослужбовиів, а також установлено взаємозв' язок вживання наркотичних речовин та скоєння військовослужбовиями кримінальних правопорушень. Ситуація сьогодення свідчить, що немедичне вживання наркотичних та психотропних речовин має тенденцію до швидкого поширення, причому вік наркоманів стабільно знижуеться. З'ясовано, що розповсюдження наркоманії серед ичивільного населення зумовлюе ї наявність $i$ серед військовослужбовиів. Серед контингенту призовників $і$ чоловіків мобілізаційного віку сформувалася велика частка осіб, які мають досвід вживання наркотиків. Доведено, що наркоманія несумісна з військовою службою, яка відрізняється напруженою інтелектуальною діяльністю, виконанням обов'язків, що вимагають значних фізичних $i$ психологічних навантажень. Наркотизаиія у військових формуваннях створює серйозні передумови для надзвичайних подій ma аварійних ситуацій із непередбаченими наслідками, сприяе поширенню девіацій, пери за все суїцидальних проявів, призводить до небойових втрат серед військовослужбовциів. Зазначено, що щзорічно простежується зростання наркозлочинності військовослужбовиів. На трунті вживання наркотиків скоюються загальнокримінальні та «військові» кримінальні правопорушення. Наркотизація виступає однією з причин віктимізації військовослужбовців, у сукупності з іншими формами правопорушуючої поведінки формує деструктивні чинники в організаціі бойової діяльності військових формувань, виступає одним з джерел економічного "підживлення» корупиіі у військових формуваннях. Підкреслено, що війська специфічна частина суспільства зі своїми соціально-економічними, демографічними, організаційно-управлінськими і правовими особливостями. Тому поряд із загальним комплексом криміногенних чинників, що притаманні суспільству загалом, специфічними для військового середовища криміногенними факторами $\epsilon$ також дія комплексу психотравмуючих ситуацій. Викладені прин-

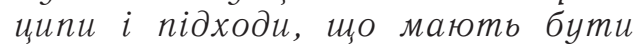
покладені в основу профілактики та протидіï наркотизаціï та наркозлочинній поведінці військовослужбовизів.

Ключові слова: військовослужбовці, військова служба, наркоманія, наркотизм, криміногенні чинники, наркотичні речовини, профілактика наркоманіі, протидія наркозлочинності.

Hradetskyi A., Povar O. NARCOTICS OF SERVICEMEN AS A SOCIAL AND LEGAL PROBLEM Drug addiction has become a threatening challenge for Ukraine to the nation and the state. The article examines the problems of the spread of drug addiction among servicemen, as well as establishes the relationship between drug use and the commission of criminal offenses by servicemen. The current situation shows that non-medical use of narcotic drugs and psychotropic substances tends to spread rapidly, and the age of drug addicts is steadily declining. It has been found that the spread of drug

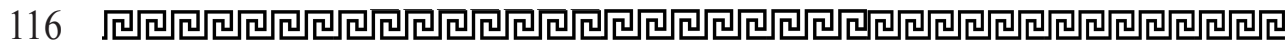


addiction among the civilian population determines its presence among the military. Among the contingent of conscripts and men of mobilization age, a large number of people with experience in drug use have formed. It is confirmed that drug addiction is incompatible with military service, which is characterized by intense intellectual activity, the performance of duties that require significant physical and psychological stress. Narcotization in military formations creates serious preconditions for accidents and emergencies with unforeseen consequences, contributes to the spread of deviations, especially suicidal acts, and leads to non-combat casualties among servicemen. It is noted that there is an annual increase in drug crime among servicemen. General criminal and "military" criminal offenses are committed on the basis of drug use. Narcotization is one of the reasons for victimization of servicemen, in combination with other forms of offensive behaviour forms destructive factors in the organization of combat activities of military formations, acts as one of the sources of economic "feeding" corruption in military formations. It is emphasized that the troops - a specific part of society, with its socio-economic, demographic, organizational, managerial and legal characteristics. Therefore, along with the general set of criminogenic factors that are inherent in society as a whole, specific to the military environment criminogenic factors are also the actions of a complex of traumatic situations. The principles and approaches that should be the basis for the prevention and counteraction of narcotization and drug-criminal behaviour of servicemen are stated.

Key words: servicemen, military service, drug addiction, narcotics, criminogenic factors, narcotic substances, drug prevention, counteraction to drug crime.

\section{Література}

1. Коиур М.м. Правове регулювання протидіi незаконному обігу наркотичних засобів, психотропних речовин та прекурсорів (історико-правове дослідження) : автореф. дис. ... канд. юрид. наук : 12.00.01. Приват. ВНЗ «Ун-m Короля Данила». Івано-Франківськ, 2020. $20 \mathrm{c}$.

2. Наркозлочинність : кримінологічна характеристика та запобігання : Науковий практичний посібник / А.А. Бова, B.I. Женунтій, А.П. Закалюк та ін. Київ, 2006. 296 C.

3. Котляренко Л.Т. Протидія наркоманії у Збройних силах України. Основні напрями та проблеми протидії наркоманії : матеріали круглого столу, м. Київ, 6 лют. 2017 р. Івано-Франківськ : Наи. акад. внутр. справ, 2017. 122 с.

4. Хрупnа М.С., Павленко P.М., Семенюк В.А. Діяльність дільничних інспекторів міліції по запобіганню наркотизму : науково-практичний нарис. Київ, 2001. $140 \mathrm{c}$.

5. Профілактика відхильної поведінки у військовослужбовців : навчально-методичний посібник / A.M. Романишин, T.M. Мацевко та ін. Львів : НАСВ, 2017. 322 c.

6. Гузенко I.M. Прояви девіантной поведінки серед учасників бойових дій та ї профілактика. Психологія національної безпеки $і$ благополуччя особистості : тези I Міжнародної науково-практичної конференції, м. Львів 14-15 березня 2019 року. Львів : Видавництво Львівської політехніки, 2019. С. 50-51.

7. Контроль наркологічної ситуацї та ранне виявлення військовослужбовців, які вживають психоактивні речовини : навчальнии посібник / I.I. Приходько, Я.В. Мацегора, І.В. Воробйова та ін. 2-ге вид. Харків : НА НГУ, 2016. $107 \mathrm{c}$.

8. Харабет К.В. Противодействие наркотизму и наркопреступности в Вооруженных силах Российской Федерации (социально-правовое и криминологическое исследование) : диссертаиия ... д-ра юридических наук : 12.00.08. ФГКОУ ВО «ниверситет прокуратуры Российской Федерации. Москва, 2018. 396 с.

9. Раєиька Л.В. Детермінанти потирення наркоманіі в Україні. Боротьба з організованою злочинністю $і$ корупцією (теорія $і$ практика). 2007. Bun. 17. C. 284-290. 


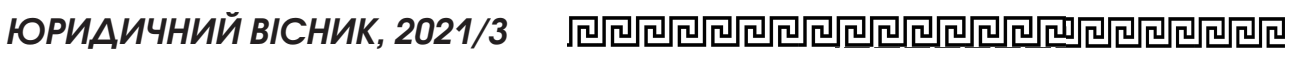

10. Приходько I.I., Байда М.C. Теоретичні аспекти адиктивної поведінки військовослужбовців. Честь $і$ закон. 2018. № 3 (66). C. 67-74.

11. Наумов В.Л. Схильність до адиктивної поведінки учасників АТО з розладами адаптаціï, посттравматичними стресовими розладами та постстресовим розладом особистості. Український вісник психоневрологіі. 2018. T. 26. Bun. 4. C. 73-76.

12. Гладкова E.О. Особливості феномена наркозлочинності в Україні у сучасних умовах. Вісник кримінологічної асоціації України. 2019. № 1(20). C. 56-65.

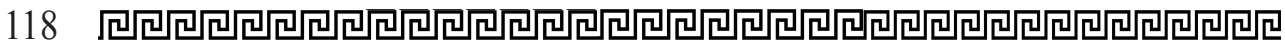

